\title{
Sytematic Literature Review: Strategi Intervensi Penanganan Pandemi Covid-19 dalam Sudut Pandang Teknologi Informasi \\ 1* Aan Erlansari, ${ }^{2}$ Mochammad Yusa, , ${ }^{3}$ Liya A. Umar \\ ${ }^{1,2,3}$ Universitas Bengkulu, Bengkulu, Indonesia
}

E-mail:, ' $a a n \_e r l a n s h a r i @ u n i b . a c . i d,{ }^{2}$ mochammad.yusa@unib.ac.id, ${ }^{3}$ liya@unib.ac.id,

\begin{tabular}{|c|c|c|}
\hline \multicolumn{3}{|l|}{ Article Info } \\
\hline \multicolumn{3}{|c|}{ Article history: } \\
\hline \multicolumn{3}{|c|}{$\begin{array}{l}\text { Received, 13/11/2021 } \\
\text { Revised, 19/11/2021 } \\
\text { Accepted, 23/11/2021 }\end{array}$} \\
\hline \multicolumn{3}{|l|}{ Kata Kunci: } \\
\hline $\begin{array}{l}\text { Pandemi } \\
\text { Intervensi, T } \\
\text { pencegahan } \\
\text { pencegahan ta }\end{array}$ & $\begin{array}{l}\text { Covid-19, } \\
\text { Teknologi } \\
\text { dengan } \\
\text { tanpa obat }\end{array}$ & $\begin{array}{r}\text { Strategi } \\
\text { Informasi, } \\
\text { obat, }\end{array}$ \\
\hline
\end{tabular}

Covid-19 Pandemic, Intervention Strategy, Information Technology, pharmaceutical intervention, nonpharmaceutical intervention

\section{ABSTRAK}

Covid-19 merupakan jenis virus baru yang sampai saat ini belum ditemukan obat/antivirus/treatment yang pasti. Penelitian yang dilakukan dan dijelaskan dalam paper ini adalah untuk mengetahui sudut pandang (perspektif) teknologi informasi. Perspective yang dibangun dalam paper ini juga menilik bagaimana teknologi informasi dapat digunakan untuk menangani pandemic-pandemi sebelum Covid19. Metode penelitian yang digunakan merupakan adaptasi dari penelitian Literatur Review Sistematis yang dilakukan oleh Kitchenham. Dalam paper ini juga akan dibahas tentang strategi intervensi penyebaran Covid-19 diataranya adalah intervensi menggunakan obat (pharmaceutical) dan non-obat (nonpharmaceutical). Pada studi ini juga akan dibahas tentang teknologi informasi yang sudah pernah digunakan di bidang kesehatan sebagai upaya pencegahan penyebaran pandemic-pandemi baik Covid-19 ataupun pandemic lainnya yang pernah terjadi di beberapa negara. Model strategi ini memungkinkan untuk dikembangkan menjadi penelitian selanjutnya untuk dasar penentuan kebijakan strategi berdasarkan penomena yang terjadi yang didasarkan pada data yang di-generate oleh pengguna. Model strategi ini diharapkan bisa dijadikan alternatif strategi untuk menekan biaya belanja pemerintah dan mempersempit ruang gerak transmisi Covid-19

\section{ABSTRACT}

Covid-19 is a new type of virus for which no definitive drug / antiviral I treatment has yet been found. What will describe in this paper is to determine the point of view of mitigation strategy related to information technology perspective. We also look at how information technology can be used to deal with pandemics before Covid-19. The research method used is an adaptation of the Systematic Review Literature research conducted by Kitchenham. This paper discusses intervention strategies for preventing Covid-19 pandemic including interventions using drugs (pharmaceuticals) and non-pharmaceuticals (non-pharmaceuticals). We also discuss about how Information Technology can be an alternative in the health sector to prevent the spread of Covid-19 pandemics or other pandemics that have occurred in several countries before. This strategy model allows it to be developed into further research for the basis for determining strategic policies based on the occurrences that occur based on user-generated data. It is hoped that this strategic model can be used as an alternative strategy to reduce government spending costs and narrow the space for the transmission of Covid-19.

This is an open access article under the CC BY-SAlicense. 


\section{Penulis Korespondensi:}

Aan erlansari,

Program Studi sistem informasi,

Universitas Bengkulu,

Email: aan_erlanshari@unib.ac.id

\section{PENDAHULUAN}

COVID (Corona Virus Disease) 19 merupakan virus baru di dunia yang pertama kali ditemukan di kota Wuhan Provinsi Hubei, Cina [1]. Hasil dai analisis genomic menunjukkan bahwa COVID-19 merupakan familia dari Severe Acte Respitarory Syndrome-Like (SARS-Like) atau jenis yang disebabkan oleh kelelawar [2]. Sejak pertama kali kemunculan pandemi sampai dengan saat ini, World Health Organization (WHO) telah mencatat 1.279 .722 kasus terkonfirmasi dan penderita yang dinyatakan meninggal sebanyak 72.614 orang atau bertambah sebanyak 5.050 orang sampai dengan tanggal 7 April 2020 di seluruh dunia [3]. Di Indonesia sendiri, kasus pertama diumumkan pada tanggal 2 Maret 2020. Kasus COVID-19 memiliki tingkat kecenderungan kematian yang tinggi di Indonesia. Sampai dengan tanggal 8 April 2020, angka mortalitas kasus pendemi COVID-19 di Indonesia mencapai 8,12\% persen dengan jumlah penderita sebanyak 2.956 orang. Setiap harinya kurva kasus infeksi COVID-19 baru cenderung menunjukkan curva yang tajam ke atas yang berarti kenaikan transmisi COVID-19 sangat cepat[4]. Penyebaran Covid-19 dari manusia ke manusia ditularkan melalui kontak langsung atau melalui sebaran tetesan (droplet) langsung yang ditimbulkan bersin dan batuk dari individu yang terinfeksi COVID-19 [5].

Studi-studi menyebutkan bahwa terdapat beberapa pola karakteristik transimisi pasien-pasien yang terinfeksi Covid-19. Karakteristik-karakteristik tersebut adalah pasien dengan gejala, dengan gejala ringan, tanpa gejala, dan tidak ada pneumonia yang diidapnya[6]-[8]. Manifestasi pasien postif Covid-19 dengan gejala memiliki beberapa spektrum. Spectrum tersebut dapat bermula dari tidak munculnya gejala, gejala ringan, pneumonia, pneumonia berat, ARDS, sepsis, sampai dengan syok sepsis[9]. Masa inkubasi virus dari onset Covid-19 berkisar antara 2-14 hari[10]. Dengan edukasi tentang gejala-gejala karakteristik Covid-19, masyarakat akan lebih waspada dengan orang-orang dengan gejala yang nampak saja. Karakteristik yang kedua adalah pasien positif dengan gejala ringan yaitu pasien yang hanya mengalami beberapa gejala ringan misalnya batuk kering, pusing, dan gejala-gejala yang lain. Dari 76 pasien postif Covid-19 di rumah sakit Nanyang, Cina, 61\% dikategorikan sebagai pasien positif dengan gejala-gejala ringan[11]. Dalam beberapa kasus di US dan China, penyebaran COVID-19 berasal bukan dari pasien terjangkit yang sedang dirawat di Rumah Sakit, tetapi berasal dari individu yang terinfeksi namun tidak memiliki gejala (asymptomatic) atau hanya memiliki gejala ringan[8], [12], [13]. Potensi meluasnya penyebaran Covid-19 melalui individu yang memiliki gejala ringan bahkan tanpa gejala sangat besar sehingga butuh suatu model mitigasi sebagai upaya tindakan preventif meluasnya wabah virus ini.

Di Indonesia, intevensi mitigasi kemungkinan penyebaran yang ditularkan oleh individu yang tanpa gejala terus dilaksanakan seperti rapid diagnostic test berskala besar[14], pembatasan sosial berskala besar, social distancing, dan penghindaran kegiatan-kegiatan sosial. Namun Real-Time Polymerase Chain Reaction (RT-PCR) test menggunakan sampel yang jumlahnya terbatas sehingga sensitivitas masih rendah dan harus dilaksanakan menggunakan SWAB test untuk mengetahui apakah individu benar-benar terinfeksi Covid-19 [15], [16]. Bagaimanapun Rapid Test yang diimplementasikan di Indonesia hanya dapat mendeteksi pasien yang sudah terinfeksi selama 7 hari onset (dimulainya gejala) [14]. Struktur geografis yang besar dan mobilitas yang tinggi sangat memungkinkan terdapat beberapa orang yang bekerja ataupun kuliah di daerah terjangkit pulang ke daerah asal [17]. RT-PCR hanya dilakukan di fasilitas kesehatan pemerintah. Jarak rumah yang jauh dari fasilitas kesehatan memungkinkan masyarakat untuk enggan melakukan pengecekan jika terdapat gejala khususnya di daerah-daerah terpencil. Hal ini membuat kontrol penyebaran Covid-19 menjadi sangat berisiko.

Fleksibilitas dan mobilitas menjadi isu yang menarik dalam memonitoring kemungkinan transmisi wabah Covid-19. Di bidang teknologi informasi, sistem elektronis dapat menjadi solusi untuk mengatasi memprediksi, mencegah, membantu membuat keputusan yang tepat dalam mitigasi virus yang menular [18]. Sistem pakar merupakan representasi pengetahuan seorang pakar yang dapat digunakan untuk konsultasi secara interaktif melalui media maintream seperti mobile maupun website[19]-[21]. Sistem pakar memungkinkan juga memberikan edukasi terhadap orang awan tentang rekomendasi penanganan terhadap suatu penyakit berdasarkan pengetahuan dari pakar dalam upaya pencegahan penyebaran [20], [22], [23].

Ditengah ketidakpastian manifestasi klinis dari transmisi Covid-19 dari individu yang tidak memiliki gejala dan reaksi kemunculan gejala yang berkisar antara 2 sampai dengan 14 hari, tindakan mitigasi untuk 
intervensi transimisi Covid-19 menjadi sangat penting. Mitigasi dengan obat dan tidak dengan obat (nonpharmaceutical) menjadi ujung dari tindakan preventif dan intervensi penyebaran virus ini. Berbagai upaya intervensi untuk screening penyebaran seperti social distancing, PSBB, rapid test berskala besar dirasa kurang efektif dalam mendeteksi dan melacak individu yang terinfeksi mengingat struktur demografis, keuangan negara, dan fleksibilitas program. Pada penelitian pendahulu membahas tentang sistem pakar terhadap Implementasi Metode Bayes Probabilties untuk Penentuan Kriteria Pasien COVID-19 Berdasarkan Fitur Gejala Dalam paper ini, sebuah analisis review tentang intervensi penyebaran pharmaceutical, nonpharmaceutical yang sangat fleksibel akan dibahas dengan pendekatan teknologi sistem informasi dalam upaya penanganan pandemic sebelumnya

\section{METODE PENELITIAN}

Penelitian ini merupakan penelitian yang mengimplementasikan methodology SLR (Systematic Literature Review). Metode penelitian yang digunakan merupakan adaptasi dari penelitian SLR yang dilakukan oleh Kitchenham[24]. Adaptasi methodology yang dilakukan juga menilik pada penelitian [25]. Dalam penelitian [25] tersebut, focus terhadap bidang yang akan direview menjadi sangat spesifik. Terdapat beberapa strategi guna mengintervensi penyebaran Covid-19 diataranya adalah intervensi menggunakan obat (pharmaceutical) dan non-obat (non-pharmaceutical). Pada studi ini juga akan dibahas tentang teknologi informasi yang sudah pernah digunakan di bidang kesehatan sebagai upaya pencegahan penyebaran pandemic-pandemi baik Covid19 ataupun pandemic lainnya yang pernah terjadi di beberapa negara. Gambar 1 meupakan gambaran metode penelitian yang akan diimplementasikan dalam studi ini. Penelitian ini dimulai dengan pencarian artikel, prosiding konferensi pada database paper seperti Elsevier, science direct, dan google scholar. Kata kunci yang digunakan secara garis besar terdapat 2 (dua) yaitu "Covid Mitigation Strategy pharmaceutical dan nonpharmaceutical". Dari hasil pencarian kata kedua kata kunci tersebut selanjutnya untuk mitigasi nonpharmaceutical ditambahkan dengan strategi penanganan pandemic dengan pemanfaatan system informasi atau system expert. Dari hasil-hasil artikel maupun prosiding yang didapat kemudian paper tersebut diskimming dengan cara membaca judul dan abstrak untuk mendapatkan data yang paling relevan. Dari data paper yang dianggap relevan kemudian paper tersebut akan direview dan dianalisis sebagai pendahuluan dalam menentukan research question yang menjadi fondasi penelitian selanjutnya.

\section{HASIL DAN ANALISIS}

Setelah melakukan penelusuran kata kunci seperti yang ditunjukkan pada chapter II, maka didaptkan paper yang relevan terkait dengan mitigasi pandemic secara pharmaceutical, non-pharmaceutical dan teknologi informasi yang mendukung pencegahan transmisi penyakit yang menular.

\section{A. Strategi Mitigasi Intervensi Pharmaceutical}

Penyebaran virus Covid-19 merupakan dampak yang sangat luar biasa. Sampai dengan saat ini, belum ditemukannya obat atau vaksin yang spesifik untuk menyembuhkan Covid-19 [26], [27]. Manifestasi klinis sudah dilakukan melalui investigasi untuk menemukan pola reaksi virus berdasarkan gejala-gejala yang dialami oleh penderita COVID-19/SARS-COV-2 [28], [29].

Strategi mitigasi menggunakan obat (pharmaceutical) dilakukan oleh [30], penggunaan antigen bernama Favipiravir (FVP) yang menunjukkan hasil cukup menjanjikan namun belum sepenuhnya dapat menyembuhkan individu yang terinfeksi. Kemudian [31] mencoba treatment terhadap pasien terinfeksi menggunakan FVP dan Lovinapir (LVP). Hasil penelitian menunjukkan bahwa perlakuan dengan memberikan FVP meningkatkan penyembuhan pasien yang dirawat di rumah sakit. Penelitian-penelitian merupakan mitigasi yang dilakukan di dalam rumah sakit terhadap pasien yang dirawat. Namun mitigasi menggunakan obat/vaksin/antivirus bisa dilaksanakan jika pasien sudah positif terinfeksi dan dirawat pada fasilitas kesehatan tertentu dan bukan untuk mengatasi masalah mitigasi dalam penyebaran dari human-carrier yang lainnya khususnya yang bergejala ringan (mild-symptomatic) dan tidak bergejala (asymptomatic). Sehingga dapat disebutkan bahwa sampai dengan saat ini belum ada mitigasi pharmaceutical yang tepat dan berhasil dalam menangani pandemic Covid-19 ini.

\section{B. Strategi Mitigasi Intervensi non-pharmaceutical}

Guna mempersempit ruang gerak penyebaran virus ini, beberapa stategi mitigasi non-pharmaceutical telah diterapkan di berbagai negara di seluruh dunia. Misalnya melaui penerapan model mitigasi agent-based berbasis komputasi yang mempertimbangkan faktor-faktor seperti jumlah reproduksi, masa periode inkubasi dan generasi, tingkat penyebaran berdasarkan usia, tingkat pertumbuhan kasus komulatif selama tidak ada 
tindakan mitigasi yang berkelanjutan [32]. Dalam penelitian tersebut disebutkan bahwa kepatuhan sosial memiliki pengaruh yang tinggi yaitu sebesar $70-80 \%$. Untuk wilayah yang memiliki tingkat kepatuhan terhadap kebijakan di atas 90\% maka dapat mengatasi pandemi ini selama 12-14 minggu. Kemudian mitigasi yang dilakukan oleh negara China dengan menerapkan kebijakan isolasi, karantina mandiri, sosial distancing, dan pelarangan berkumpul[26]. Penelitian lain yang dilakukan Workman et al. (2020) dengan mensimulasikan penularan infeksi virus yang dialami oleh dokter bedah tulang yang secara signifikan sangat mungkin tertular COVID-19 pada saat menangani pasien. Kesimpulan riset tersebut menghasilkan penyebaran melalui proses aerolisasi pada dokter bedah endonasal memungkinkan terjadinya penyebaran Covid-19 sehingga dibutuhkan mitigasi yang aman dalam menangani pasien terinfeksi melalui prosedur penanganan pasien yang tepat. Hasil penelitian lainnya [34] menyarankan bahwa pemeriksaan masal pada jenjang waktu setiap 10 hari terhadap orang yang tanpa gejala merupakan strategi yang sangat menjanjikan dalam upaya menghentikan penyebaran Covid-19 di negara Swiss. Namun dengan struktur geografis yang besar dan jumlah penduduk yang banyak tentunya berbanding lurus dengan biaya yang besar dan banyaknya tenaga medis yang disebarkan serta respon kesiapsiagaan pemerintah yang dinilai masih kurang[17].

\section{Intervensi Pandemi dengan Teknologi Informasi}

Transmisi Covid-19 yang cepat dengan pola yang tidak teridentifkasi serta masa inkubasi yang berdurasi 1-2 minggu [35], dirasa perlu memodelkan strategi mitigasi berbasis teknologi untuk mengitervensi penyebaran melalui orang yang tanpa gejala. Beberapa penelitian yang memanfaatkan teknologi dalam pengambilan suatu keputusan dan expert system terkait dengan penyakit klinis sudah sering dilakukan untuk dapat digunakan terhadap pasien rawat inap [36]-[41]. Namun untuk kasus pandemi Covid-19 yang tergolong sangat baru masih sedikit dan belum ada pola yang jelas terkait dengan gejala yang diderita oleh individu yang terinfeksi. Maka dari itu penting untuk dibuatkan sebuah interaktif sebuah program aplikasi yang dapat mendiagnosis berdasarkan gejala yang dihadapi. Studi [42], game elektronis (e-game) kesehatan merupakan salah satu intervensi yang sangat efektik karena dalam game memungkinkan pengguna mendapatkan edukasi tentang kesehatan untuk mempersempit transmisi penyakit endemi maupun pandemi dengan cara yang atraktif dan menghibur. Intervensi deteksi dini penyakit menggunakan hasil gambar ronsen bagian dada (CT scan) untuk pandemi COVID-19 [43] dan penyakit pandemi lainnya [44], [45] sudah diimplemntasikan. Namun penelitian tersebut hanya dapat menangani pasien yang sedang dirawat inap di rumah sakit dengan fasilitas laboratorium kesehatan yang baik.

Detail dari analisis review dapat dilihat pada Tabel 1 berikut.

TABLE I. TABel 1. DETAIL REVIEW ANALISIS PAPER YANG RELEVAN

\begin{tabular}{|c|c|c|c|c|c|}
\hline No & Judul & $\begin{array}{l}\text { Peneliti, } \\
\text { Tahun }\end{array}$ & $\begin{array}{l}\text { Tujuan } \\
\text { Penelitian }\end{array}$ & Kesimpulan & $\begin{array}{l}\text { Saran atau } \\
\text { kelemahan }\end{array}$ \\
\hline 1 & $\begin{array}{l}\text { SOCRATES: } \\
\text { An online tool } \\
\text { leveraging a } \\
\text { social contact } \\
\text { data sharing } \\
\text { initiative to } \\
\text { assess } \\
\text { mitigation } \\
\text { strategies for } \\
\text { COVID-19 }\end{array}$ & [46] & $\begin{array}{l}\text { Membangun inisiatif } \\
\text { berbagi data kontak } \\
\text { sosial dan alat online } \\
\text { untuk menilai strategi } \\
\text { mitigasi untuk } \\
\text { COVID-19. }\end{array}$ & $\begin{array}{l}\text { memanfaatkan data kontak } \\
\text { sosial yang tersedia dapat } \\
\text { memetakan pergerakan } \\
\text { passien sehingga dapa } \\
\text { menjadi sebuah strategi } \\
\text { intervensi untuk mengurang } \\
\text { penyebaran Covid-19. }\end{array}$ & $\begin{array}{l}\text { Hanya } \\
\text { memperhitungkan } \\
\text { pola kontak sosial } \\
\text { yang disesuaikan } \\
\text { dan tidak } \\
\text { memperhatikan } \\
\text { kelompok usia } \\
\text { maupun pekerjaan. }\end{array}$ \\
\hline 2 & $\begin{array}{l}\text { Modelling } \\
\text { transmission } \\
\text { and control of } \\
\text { the COVID-19 } \\
\text { pandemic in } \\
\text { Australia }\end{array}$ & [32] & $\begin{array}{l}\text { mengembangkan } \\
\text { model berbasis agen } \\
\text { untuk simulasi } \\
\text { komputasi berbutir } \\
\text { halus dari pandemi } \\
\text { COVID-19 yang } \\
\text { sedang berlangsung } \\
\text { di Australia. Model } \\
\text { ini dikalibrasi untuk } \\
\text { mereproduksi } \\
\text { beberapa karakteristik } \\
\text { transmisi COVID-19, } \\
\text { memperhitungkan } \\
\text { jumlah }\end{array}$ & $\begin{array}{l}\text { transisi penting di seluruh } \\
\text { level kepatuhan terhadap } \\
\text { kebijakan sosial distancing } \\
\text { berkisar antara } 70 \% \text { dan } \\
80 \% \text {. Hal ini menunjukkan } \\
\text { bahwa kepatuhan di bawah } \\
70 \% \text { tidak mungkin } \\
\text { berhasil selama durasi jarak } \\
\text { sosial, sedangkan } \\
\text { kepatuhan pada tingkat } \\
\text { 90\% kemungkinan akan } \\
\text { mengendalikan penyakit } \\
\text { dalam 13-14 minggu, } \\
\text { ketika ditambah dengan }\end{array}$ & $\begin{array}{l}\text { struktur geografis } \\
\text { spesifik yaitu di } \\
\text { negara australia } \\
\text { sehingga kultur } \\
\text { menjadi maslah } \\
\text { yang harus } \\
\text { dipecahkan dan } \\
\text { struktur geografis } \\
\text { juga menjadi } \\
\text { problem dalam } \\
\text { menentukan NpI } \\
\text { yang tepat sebagai } \\
\text { strategi pencegahan } \\
\text { penularan Covid- }\end{array}$ \\
\hline
\end{tabular}




\begin{tabular}{|c|c|c|c|c|c|}
\hline No & Judul & $\begin{array}{l}\text { Peneliti, } \\
\text { Tahun }\end{array}$ & $\begin{array}{l}\text { Tujuan } \\
\text { Penelitian }\end{array}$ & Kesimpulan & $\begin{array}{l}\text { Saran atau } \\
\text { kelemahan }\end{array}$ \\
\hline & & & $\begin{array}{l}\text { reproduksinya, } \\
\text { lamanya masa } \\
\text { inkubasi dan generasi, } \\
\text { laju serangan } \\
\text { bergantung usia, dan } \\
\text { laju pertumbuhan } \\
\text { insiden kumulatif } \\
\text { selama transmisi } \\
\text { lokal yang } \\
\text { berkelanjutan dan } \\
\text { tidak dikurangi. }\end{array}$ & $\begin{array}{l}\text { isolasi kasus yang efektif } \\
\text { dan pembatasan perjalanan } \\
\text { internasional. }\end{array}$ & $\begin{array}{l}\text { 19. Tingkat } \\
\text { kepatuhan yang } \\
\text { rendah di Indonesia } \\
\text { sehingga } \\
\text { dibutuhakan strategi } \\
\text { lain. }\end{array}$ \\
\hline 3 & $\begin{array}{l}\text { GIS-based } \\
\text { expert systems } \\
\text { for Land Use } \\
\text { Planning as a } \\
\text { Contribution to } \\
\text { Flood } \\
\text { Mitigation }\end{array}$ & [47] & $\begin{array}{l}\text { Memanfaatkan } \\
\text { teknologi sebagai } \\
\text { strategi mitigasi } \\
\text { bencana banjir } \\
\text { dengan } \\
\text { menambahkan } \\
\text { variabel penggunaan } \\
\text { lahan yang selama ini } \\
\text { diabaikan. Luaran } \\
\text { yang dihapkan adalah } \\
\text { tools yang dapat } \\
\text { memetakan } \\
\text { penggunaan lahar } \\
\text { sehingga dapat } \\
\text { menghindari bencana } \\
\text { banjir dan strategi } \\
\text { mitigasinya. }\end{array}$ & $\begin{array}{l}\text { Representasi yang } \\
\text { disimulasikan komputer } \\
\text { dari skenario ini, dengan } \\
\text { bantuan model curah hujan- } \\
\text { limpasan, harus secara jelas } \\
\text { menunjukkan manfaat dari } \\
\text { mengambil tindakan } \\
\text { pencegahan di daerah } \\
\text { tertentu dan dengan } \\
\text { demikian dapat } \\
\text { menunjukkan bahwa } \\
\text { potensi pengelolaan lahan } \\
\text { lebih baik digunakan } \\
\text { daripada sebelumnya. }\end{array}$ & $\begin{array}{l}\text { terdapat beberapa } \\
\text { faktor yang } \\
\text { memberdakan } \\
\text { antara mitigasi } \\
\text { penggunaan lahan } \\
\text { dengan Covid-19. }\end{array}$ \\
\hline 4 & $\begin{array}{l}\text { Targeted } \\
\text { adaptive } \\
\text { isolation } \\
\text { strategy for } \\
\text { Covid-19 } \\
\text { pandemic }\end{array}$ & {$[48]$} & $\begin{array}{l}\text { bertujuan untuk } \\
\text { menganalisis } \\
\text { kemungkinan jumlah } \\
\text { transmisi penyebaran } \\
\text { Covid-19 dengan } \\
\text { model matimatika } \\
\text { SIRA Model terhadap } \\
\text { isolasi tertarget pada } \\
\text { spesifik pasien yang } \\
\text { diduga mengidap } \\
\text { Covid-19. }\end{array}$ & $\begin{array}{l}\text { Isolasi adaptip memiliki } \\
\text { pengaruh yang bagus dalam } \\
\text { menekan angka } \\
\text { kemungkinan penyebaran } \\
\text { transmisi Covid-19. Penulis } \\
\text { juga menyimpulkan bahwa } \\
\text { hal isolasi yang adaptip } \\
\text { dapat menekan biaya } \\
\text { pengeluaran yang } \\
\text { dikeluarkan oleh } \\
\text { pemerintah. }\end{array}$ & $\begin{array}{l}\text { isolasi yang dibahas } \\
\text { adalah isolasi yang } \\
\text { adaptif terhadap } \\
\text { kelompok umur } \\
\text { tertentu dan yang } \\
\text { memiliki potensi } \\
\text { morbiditas tinggi } \\
\text { namun sumber data } \\
\text { yang digunakan } \\
\text { adalah strategi } \\
\text { dalam menangani } \\
\text { pasien yang sudah } \\
\text { pasti terinfeksi } \\
\text { Covid-19. }\end{array}$ \\
\hline 5 & $\begin{array}{l}\text { An expert } \\
\text { system for men } \\
\text { genital } \\
\text { problems } \\
\text { diagnosis and } \\
\text { treatment }\end{array}$ & [49] & $\begin{array}{l}\text { bertujuan untuk } \\
\text { mendiagnosis secara } \\
\text { mandiri untuk } \\
\text { masyarakat yang } \\
\text { memilki penyakit } \\
\text { genital. }\end{array}$ & $\begin{array}{l}\text { sistem pakar tesebut dapat } \\
\text { memberikan rekomensai } \\
\text { penanganan mandiri yang } \\
\text { signifikan. }\end{array}$ & $\begin{array}{l}\text { Posibilitas penyakit } \\
\text { genital memiliki } \\
\text { pola yang pasti. } \\
\text { SL5 Object } \\
\text { merupakan aplikasi } \\
\text { yang bersifat } \\
\text { standalone sehingga } \\
\text { hanya dapat } \\
\text { digunakan pada } \\
\text { kalangan tertentu. }\end{array}$ \\
\hline 6 & $\begin{array}{l}\text { Age Adaptive } \\
\text { Social } \\
\text { Distancing : a } \\
\text { nonlinear } \\
\text { engineering } \\
\text { strategy to } \\
\text { contrast } \\
\text { COVID-19 via } \\
\text { precision and } \\
\text { personalized } \\
\text { mitigation }\end{array}$ & {$[50]$} & $\begin{array}{l}\text { bertujuan untuk } \\
\text { mengukur keefektifan } \\
\text { Age-Adaptive Social } \\
\text { Distancing dengan } \\
\text { membagi kelompok } \\
\text { umur untuk } \\
\text { menghindari } \\
\text { terjadinya penyebaran } \\
\text { melalui 'silent } \\
\text { spreader'. }\end{array}$ & $\begin{array}{l}\text { 'silent spreaders' (usia 0- } \\
\text { 39) harus menghindari / } \\
\text { meminimalkan kontak } \\
\text { langsung dan tidak } \\
\text { langsung dengan individu } \\
\text { di 'zona berbahaya' (usia } \\
\text { 40+) untuk mengurangi } \\
\text { penyebaran Covid-19 yang } \\
\text { dapat meningkatkan angka } \\
\text { mortalitas. }\end{array}$ & $\begin{array}{l}\text { merancang strategi } \\
\text { yang presisi dan } \\
\text { personal untuk } \\
\text { penyakit menular } \\
\text { tertentu yang } \\
\text { mengintegrasikan } \\
\text { berbagai kendala } \\
\text { sosial, pengawasan } \\
\text { aktif dan } \\
\text { penelusuran kontak. }\end{array}$ \\
\hline
\end{tabular}


JSAI : Journal Scientific and Applied Informatics

Vol. 4, No. 3, November 2021, hal. 368 377

E-ISSN: 2614-3054; P-ISSN: 2614-3062, Terakreditasi Kemenristekdikti, Sinta 5

\begin{tabular}{|c|c|c|c|c|c|}
\hline No & Judul & $\begin{array}{l}\text { Peneliti, } \\
\text { Tahun }\end{array}$ & $\begin{array}{l}\text { Tujuan } \\
\text { Penelitian }\end{array}$ & Kesimpulan & $\begin{array}{l}\text { Saran atau } \\
\text { kelemahan }\end{array}$ \\
\hline 7 & $\begin{array}{l}\text { A fuzzy expert } \\
\text { system for } \\
\text { mitigation of } \\
\text { risks and } \\
\text { effective } \\
\text { control of gas } \\
\text { pressure } \\
\text { reduction } \\
\text { stations with a } \\
\text { real application }\end{array}$ & [23] & $\begin{array}{l}\text { mengusulkan sebuah } \\
\text { sistem cerdas dengan } \\
\text { pendekatan fuzzy } \\
\text { sebagai upaya } \\
\text { mitigasi risiko dan } \\
\text { kontrol yang efektif } \\
\text { pada statisun reduksi } \\
\text { tekanan gas. }\end{array}$ & $\begin{array}{l}\text { pendekatan fuzzy memiliki } \\
\text { keakuratan dalam } \\
\text { pemberian rekomendasi } \\
\text { yang tepat dalam } \\
\text { pencegahan terjadinya } \\
\text { kebocoran gas. }\end{array}$ & $\begin{array}{l}\text { hanya dalam bidang } \\
\text { tertentu, sehingga } \\
\text { adaptasi dengan } \\
\text { pendekatan } \\
\text { geografis dirasa } \\
\text { masih sangat } \\
\text { kurang. }\end{array}$ \\
\hline 8 & $\begin{array}{l}\text { Machine } \\
\text { Learning the } \\
\text { Phenomenology } \\
\text { of COVID-19 } \\
\text { From Early } \\
\text { Infection } \\
\text { Dynamics }\end{array}$ & [51] & $\begin{array}{l}\text { penelitian ini } \\
\text { menyajikan analisis } \\
\text { pembelajaran mesin } \\
\text { berbasis data pandemi } \\
\text { COVID-19 dari } \\
\text { dinamika infeksi } \\
\text { awalnya, khususnya } \\
\text { infeksi yang dihitung } \\
\text { dari waktu ke waktu. } \\
\text { Tujuannya adalah } \\
\text { untuk menggali } \\
\text { wawasan kesehatan } \\
\text { publik yang dapat } \\
\text { ditindaklanjuti. }\end{array}$ & $\begin{array}{l}\text { infeksi asimptomatik } \\
\text { (tersembunyi) yang } \\
\text { signifikan, jeda sekitar } 10 \\
\text { hari, dan kami secara } \\
\text { kuantitatif mengkonfirmasi } \\
\text { bahwa kekuatan infeksi } \\
\text { kuat dengan sekitar 0,14\% } \\
\text { transisi dari infeksi ringan } \\
\text { ke infeksi serius. }\end{array}$ & $\begin{array}{l}\text { fokus penelitian ini } \\
\text { bersumber data } \\
\text { terhitung sejak } \\
\text { kemunculan kasus } \\
\text { pertama di US. }\end{array}$ \\
\hline 9 & $\begin{array}{l}\text { Knowledge } \\
\text { Based System } \\
\text { for the } \\
\text { Diagnosis of } \\
\text { Dengue Disease }\end{array}$ & [39] & $\begin{array}{l}\text { bertujuan untuk } \\
\text { memantu tenaga } \\
\text { medis dalam } \\
\text { memonitoring } \\
\text { kemungkinan } \\
\text { kemunculan penyakit } \\
\text { dengue. }\end{array}$ & $\begin{array}{l}\text { metode knowledge-based } \\
\text { memiliki kemapuan } \\
\text { pendekatan yang baik } \\
\text { dalam mencegah terjadi } \\
\text { penyakit dengue di } \\
\text { masyarakat. }\end{array}$ & $\begin{array}{l}\text { perspektif penyakit } \\
\text { dengue memiliki } \\
\text { symptom yang } \\
\text { spesifik sehingga } \\
\text { tidak dapat } \\
\text { dimanfaatkan pada } \\
\text { penyakit tertentu. }\end{array}$ \\
\hline 10 & $\begin{array}{l}\text { Sample Pooling } \\
\text { as a Strategy to } \\
\text { Detect } \\
\text { Community } \\
\text { Transmission of } \\
\text { SARS-CoV-2 }\end{array}$ & {$[52]$} & $\begin{array}{l}\text { bertujuan untuk } \\
\text { memberikan } \\
\text { pemahaman tentang } \\
\text { tindakan preventif } \\
\text { dalam intervensi } \\
\text { penyebaran virus } \\
\text { dengan menerapkan } \\
\text { sample pooling. }\end{array}$ & $\begin{array}{l}\text { pemanfaatan metode } \\
\text { sample populasi dapat } \\
\text { mendeteksi pasien yang } \\
\text { positif sebesar } 0,07 \text { persen } \\
\text { berdasarkan data yang } \\
\text { diambil dalam } 3 \text { hari di } \\
\text { lapangan. }\end{array}$ & $\begin{array}{l}\text { pendekatan poling } \\
\text { sample } \\
\text { konvensional masih } \\
\text { dianggap kurang } \\
\text { fleksibe dan } \\
\text { mobilitasnya masih } \\
\text { rendah. }\end{array}$ \\
\hline 11 & $\begin{array}{l}\text { Web-Based } \\
\text { cancer } \\
\text { communication } \\
\text { and decision } \\
\text { making } \\
\text { systems: } \\
\text { Connecting } \\
\text { patients, } \\
\text { caregivers, and } \\
\text { clinicians for } \\
\text { improved } \\
\text { health } \\
\text { outcomes }\end{array}$ & [53] & $\begin{array}{l}\text { bertujuan untuk } \\
\text { membuat sebuah } \\
\text { system komunikasi } \\
\text { kesehatan yang } \\
\text { interaktif yang dapat } \\
\text { mengcover informasi, } \\
\text { komunikasi, sumber } \\
\text { daya yang dapat } \\
\text { membantu pasien } \\
\text { yang menderita } \\
\text { penyakit cancer dan } \\
\text { memberikan } \\
\text { bimbingan kegiatan } \\
\text { kepada keluarga } \\
\text { dalam memahami, } \\
\text { mencari dukungan } \\
\text { informasi. }\end{array}$ & $\begin{array}{l}\text { untuk menciptakan sistem } \\
\text { yang efektif, pengembang } \\
\text { sistem terintegrasi harus } \\
\text { secara komprehensif baik } \\
\text { dalam pendekatan terhadap } \\
\text { pengembangan kontennya } \\
\text { dan konten itu sendiri. }\end{array}$ & $\begin{array}{l}\text { strategi } \\
\text { implementasi harus } \\
\text { mempertimbangkan } \\
\text { waktu, personel, } \\
\text { dan faktor } \\
\text { lingkungan yang } \\
\text { terlibat, untuk } \\
\text { memastikan } \\
\text { keberhasilan } \\
\text { penyerapan dan } \\
\text { penggunaan IHCS } \\
\text { yang berkelanjutan. }\end{array}$ \\
\hline 12 & $\begin{array}{l}\text { Development } \\
\text { and Evaluation } \\
\text { of an AI } \\
\text { System for } \\
\text { COVID-19 } \\
\text { Diagnosis }\end{array}$ & [43] & $\begin{array}{l}\text { mengusulkan sistem } \\
\text { kecerdasan buatan } \\
\text { (AI) untuk diagnosis } \\
\text { COVID-19 cepat dari } \\
\text { dataset CT scan } \\
\text { dengan akurasi yang } \\
\text { sebanding dengan } \\
\text { ahli radiologi yang } \\
\text { berpengalaman. }\end{array}$ & $\begin{array}{l}\text { Dilatih hanya dengan } \\
\text { menggunakan } 312 \text { kasus, } \\
\text { sistem diagnosis yang } \\
\text { didasarkan pada Deef } \\
\text { Convolutional Neural } \\
\text { network mampu mencapai } \\
\text { akurasi } 94,98 \% \text {, AUC } \\
97,91 \%, \text { sensitivitas } \\
94,06 \% \text {, dan spesifisitas }\end{array}$ & $\begin{array}{l}\text { sistem yang } \\
\text { dibangun adalah } \\
\text { sistem yang } \\
\text { berbasis gambar } \\
\text { sehingga } \\
\text { dibutuhkan waktu } \\
\text { untuk mengambil } \\
\text { sampel diagnosis } \\
\text { dari hasil CT scan. }\end{array}$ \\
\hline
\end{tabular}




\begin{tabular}{|c|c|c|c|c|c|}
\hline No & Judul & $\begin{array}{l}\text { Peneliti, } \\
\text { Tahun }\end{array}$ & $\begin{array}{l}\text { Tujuan } \\
\text { Penelitian }\end{array}$ & Kesimpulan & $\begin{array}{l}\text { Saran atau } \\
\text { kelemahan }\end{array}$ \\
\hline & & & & $\begin{array}{l}95,47 \% \text { pada dataset } \\
\text { training sebanyak } 1.255 \\
\text { kasus. }\end{array}$ & $\begin{array}{l}\text { Fleksibilitas untuk } \\
\text { struktur geografis } \\
\text { seperti Indonesia } \\
\text { dengan fasilitas Lab } \\
\text { yang belum tersebar } \\
\text { merata akan } \\
\text { mengalami } \\
\text { kesulitan dalam } \\
\text { penerapannya. }\end{array}$ \\
\hline 13 & $\begin{array}{l}\text { An interactive } \\
\text { web-based } \\
\text { decision } \\
\text { support system } \\
\text { for mass } \\
\text { dispensing, } \\
\text { emergency } \\
\text { preparedness, } \\
\text { and } \\
\text { biosurveillance }\end{array}$ & [40] & $\begin{array}{l}\text { Penenilitian ini } \\
\text { bertujuan untuk } \\
\text { membuat sebuah web } \\
\text { interaktif yang bisa } \\
\text { digunakan untuk } \\
\text { kesiapsiagaan yang } \\
\text { dijadikan dasar untuk } \\
\text { mitigasi. Bidang } \\
\text { mitigasi yang dibahas } \\
\text { adalah insiden } \\
\text { biologis, nuklir, } \\
\text { epiemiologi, model } \\
\text { dekontaminasi. }\end{array}$ & $\begin{array}{l}\text { Pengembangan web } \\
\text { tersebut dapat digunakan } \\
\text { sebagai modal dasar dalam } \\
\text { penanganan mitigasi. } \\
\text { Model ini didasarkan pada } \\
\text { informasi umum. }\end{array}$ & $\begin{array}{l}\text { lokasi yang menjadi } \\
\text { objek adalah kota } \\
\text { Chicago US namun } \\
\text { tidak dijelaskan } \\
\text { data yang diambil } \\
\text { didasarkan dari data } \\
\text { dan informasinya. }\end{array}$ \\
\hline
\end{tabular}

Dari review artikel maupun prosiding dimana struktur review yang ditunjukkan, menjustifikasi bahwa perlu adanya inovasi teknologi berbasis system informasi yang memungkinkan dapat menjadi terobosan dalam penanggulangan penyebaran virus yang belum ditemukan antigen dalam upaya intervensi. Sehingga pada penelitian selanjutnya peneliti akan mengembangkan sebuah model yang memungkinkan untuk upaya mitigasi dalam mengintervensi transimisi Covid-19 dengan model teknologi Informasi. Penyebaran dengan tidak adanya gejala yang pasti atau gejala penyakit yang umum namun secara positif mengidap Covid-19 perlu ditangani dengan serius.

\section{KESIMPULAN (11 PT)}

Penelitian ini juga menjadi fondasi awal dalam proses pengumpulan data untuk memonitoring outpatients under surveillance (individu dalam pengawasan) atau individu yang terinfeksi dengan gejala yang menjadi indikator bahwa pasien tersebut dapat mengidap Covid-19 dengan gejala ringan dan tanpa gejala serta masa inkubasi virus yang berkisar 2-14 hari [55]. Hal ini sangat penting mengingat kondisi ekonomi dan struktur geografis yang luas maka penting untuk membuat sebuah inovasi teknologi untuk strategi intervensi transmisi sebagai upaya mitigasi non-pharmaceutical. Hasil monitoring tersebut nantinya akan dikomputasi menggunakan komputasi algoritmik untuk mengklasifikasikan alokasi tenaga maupun alat medis yang akurat untuk strategi mitagasi bencana wabah. Penelitian ini juga merupakan tahapan awal dari penelitian sustainable yang kami ajukan. Studi selanjutnya yang akan dilakukan adalah pengembangan sebauh teknologi informasi yang user-friendly dengan memanfaatkan komputasi algoritmik yang dapat menjadi suatu terobosan dalam penanganan Covid-19. Implementasi dari hasil sistem review ini ditampilkan pada [57]

\section{UCAPAN TERIMA KASIH}

Penulis mengucapkan terima kasih kepada Universitas Bengkulu yang telah memberi dukungan financial terhadap penelitian ini

\section{REFERENSI}

[1] D. S. Hui et al., "The continuing 2019-nCoV epidemic threat of novel coronaviruses to global health - The latest 2019 novel coronavirus outbreak in Wuhan, China," Int. J. Infect. Dis., vol. 91, pp. 264266, 2020, doi: 10.1016/j.ijid.2020.01.009.

[2] M. A. Shereen, S. Khan, A. Kazmi, N. Bashir, and R. Siddique, "COVID-19 infection: Origin, transmission, and characteristics of human coronaviruses," J. Adv. Res., vol. 24, pp. 91-98, 2020, doi: 10.1016/j.jare.2020.03.005.

[3] World Health Organization, "Coronavirus disease 2019-Situation Report," 2020. [Online]. Available: https://www.who.int/emergencies/diseases/novel-coronavirus-2019.

[4] Satuan Tugas Percepatan Covid-19, "Infografis Covid19 - 4 April 2020." .

[5] H. A. Rothan and S. N. Byrareddy, "The epidemiology and pathogenesis of coronavirus disease (COVID-19) outbreak," J. Autoimmun., vol. 109, no. February, p. 102433, 2020, doi: 
10.1016/j.jaut.2020.102433.

[6] Y. R. Guo et al., "The origin, transmission and clinical therapies on coronavirus disease 2019 (COVID19) outbreak - an update on the status," Mil. Med. Res., vol. 7, no. 1, p. 11, 2020, doi: 10.1186/s40779020-00240-0.

[7] S. Murthy, C. D. Gomersall, and R. A. Fowler, "Care for Critically Ill Patients with COVID-19," JAMA - J. Am. Med. Assoc., pp. 1-2, 2020, doi: 10.1001/jama.2020.3633.

[8] S. Tian et al., "Characteristics of COVID-19 infection in Beijing," J. Infect., vol. 80, no. 4, pp. 401406, 2020, doi: 10.1016/j.jinf.2020.02.018.

[9] K. Kam et al., "A Well Infant With Coronavirus Disease 2019 With High Viral Load," Clin. Infect. Dis., no. February, pp. 2019-2021, 2020, doi: 10.1093/cid/ciaa201.

[10] S. A. Lauer et al., "The Incubation Period of Coronavirus Disease 2019 (COVID-19) From Publicly Reported Confirmed Cases: Estimation and Application," Ann. Intern. Med., vol. 2019, 2020, doi: 10.7326/m20-0504.

[11] Y. Liu et al., "Viral dynamics in mild and severe cases of COVID-19," Lancet Infect. Dis., vol. 2019, no. 20, pp. 2019-2020, 2020, doi: 10.1016/S1473-3099(20)30232-2.

[12] S. M. Parodi and V. X. Liu, "From Containment to Mitigation of COVID-19 in the US," JAMA Netw. Am. Med. Assoc., pp. E1-E2, 2020, doi: 10.1001/jama.2020.3882.

[13] H. Nishiura, N. M. Linton, and A. R. Akhmetzhanov, "Serial interval of novel coronavirus (COVID19) infections," Int. J. Infect. Dis., vol. 93, pp. 284-286, 2020, doi: 10.1016/j.ijid.2020.02.060.

[14] ANTARA, "Indonesia to Prepare Rapid Test for Coronavirus Detection," Medcom.id, Jakarta, 2020.

[15] D. Kiselev, A. Matsvay, I. Abramov, V. Dedkov, G. Shipulin, and K. Khafizov, "Detection of a novel human coronavirus by real-time reverse-transcription polymerase chain reaction," Euro Surveill., vol. 17, no. 39, pp. 1-6, Feb. 2012, doi: 10.3390/v12020211.

[16] D. Kiselev, A. Matsvay, I. Abramov, V. Dedkov, G. Shipulin, and K. Khafizov, "Current Trends in Diagnostics of Viral Infections of Unknown Etiology," Viruses, vol. 12, no. 211, pp. 1-28, 2020, doi: 10.3390/v12020211.

[17] A. Sudjatma et al., "Review and Analysis of Current Responses to COVID-19 in Indonesia: Period of January to March 2020," Prog. Disaster Sci., no. march, 2020, doi: 10.1016/j.pdisas.2020.100091.

[18] E. Christaki, "New technologies in predicting, preventing and controlling emerging infectious diseases," Virulence, vol. 6, no. 6, pp. 558-565, 2015, doi: 10.1080/21505594.2015.1040975.

[19] X. Wang, H. Qu, P. Liu, and Y. Cheng, "A self-learning expert system for diagnosis in traditional Chinese medicine," vol. 26, pp. 557-566, 2004, doi: 10.1016/j.eswa.2003.10.004.

[20] I. Demirkiran, D. D. Weiner, A. Drozd, and I. Kasperovich, "Knowledge-based approach to interference mitigation for EMC of transceivers on unmanned aircraft," IEEE Int. Symp. Electromagn. Compat., pp. 425-430, 2010, doi: 10.1109/ISEMC.2010.5711312.

[21] S. S. A. Naser and B. G. Bastami, "A Proposed Rule Based System for Breasts Cancer Diagnosis," World Wide J. Multidiscipl Ina. Res. Dev. WWJMRD, vol. 2, no. 5, pp. 27-33, 2016.

[22] S. Simpson, M. C. Kaufmann, V. Glozman, and A. Chakrabarti, "Disease X: accelerating the development of medical countermeasures for the next pandemic," Lancet Infect. Dis., vol. 3099, no. 20, pp. 1-8, 2020, doi: 10.1016/S1473-3099(20)30123-7.

[23] R. Nourian, S. M. Mousavi, and S. Raissi, "A fuzzy expert system for mitigation of risks and effective control of gas pressure reduction stations with a real application," J. Loss Prev. Process Ind., vol. 59, pp. 77-90, 2019, doi: 10.1016/j.jlp.2019.03.003.

[24] B. Kitchenham et al., "Systematic literature reviews in software engineering-A tertiary study," Inf. Softw. Technol., vol. 52, no. 8, pp. 792-805, 2010, doi: 10.1016/j.infsof.2010.03.006.

[25] E. Utami, Mihuandayani, A. D. Hartanto, M. Yusa, and S. Raharjo, "Systematic Literature Review of Profiling Analysis Based on Social Media,” 2019.

[26] M. Jennifer, "Characteristics of and Important Lessons From the Coronavirus Disease 2019 ( COVID19 ) Outbreak in China Summary of a Report of 72314 Cases From the Chinese Center for Disease Control and Prevention," vol. 2019, 2020.

[27] K. Panati and V. R. Narala, "COVID-19 Outbreak: an Update on Therapeutic Options," SN Compr. Clin. Med., pp. 3-4, Apr. 2020, doi: 10.1007/s42399-020-00264-6.

[28] F. Zhou et al., "Clinical course and risk factors for mortality of adult inpatients with COVID-19 in Wuhan, China: a retrospective cohort study," Lancet, vol. 395, no. 10229, pp. 1054-1062, 2020, doi: 10.1016/S0140-6736(20)30566-3.

[29] P. Zhai, Y. Ding, X. Wu, J. Long, Y. Zhong, and Y. Li, "The epidemiology, diagnosis and treatment of COVID-19," Int. J. Antimicrob. Agents, p. 105955, 2020, doi: 10.1016/j.ijantimicag.2020.105955.

[30] Q. Cai et al., "Experimental Treatment with Favipiravir for COVID-19: An Open-Label Control Study," Engineering, 2020, doi: 10.1016/j.eng.2020.03.007.

[31] L. Dong, S. Hu, and J. Gao, "Discovering drugs to treat coronavirus disease 2019 (COVID-19)," Drug Discov. Ther., vol. 14, no. 1, pp. 58-60, 2020, doi: 10.5582/ddt.2020.01012. 
[32] S. L. Chang, N. Harding, C. Zachreson, O. M. Cliff, and M. Prokopenko, "Modelling transmission and control of the COVID-19 pandemic in Australia," Preprints, 2020, [Online]. Available: http://arxiv.org/abs/2003.10218.

[33] A. D. Workman et al., "Endonasal Instrumentation and Aerosolization Risk in the Era of COVID-19: Simulation, Literature Review, and Proposed Mitigation Strategies," Preprint, 2020, doi: https://doi.org/10.1111/alr.22577.

[34] P. Jenny, D. F. Jenny, H. Gorji, M. Arnoldini, and W.-D. Hardt, "Dynamic Modeling to Identify Mitigation Strategies for Covid-19 Pandemic," medRxiv, p. 2020.03.27.20045237, 2020, doi: 10.1101/2020.03.27.20045237.

[35] R. M. Anderson, H. Heesterbeek, D. Klinkenberg, and T. D. Hollingsworth, "How will country-based mitigation measures influence the course of the COVID-19 epidemic ?," Lancet, vol. 395, no. 10228, pp. 931-934, 2020, doi: 10.1016/S0140-6736(20)30567-5.

[36] A. Zlojutro, D. Rey, and L. Gardner, "A decision-support framework to optimize border control for global outbreak mitigation," Sci. Rep., vol. 9, no. 1, pp. 1-14, 2019, doi: 10.1038/s41598-019-38665w.

[37] A. Sanz-Paris et al., "Evidence-based recommendations and expert consensus on enteral nutrition in the adult patient with diabetes mellitus or hyperglycemia," Nutrition, vol. 41, pp. 58-67, 2017, doi: 10.1016/j.nut.2017.02.014.

[38] A. Belard et al., "Precision diagnosis: a view of the clinical decision support systems (CDSS) landscape through the lens of critical care," J. Clin. Monit. Comput., vol. 31, no. 2, pp. 261-271, 2017, doi: 10.1007/s10877-016-9849-1.

[39] A. I. Mansour and S. S. Abu-naser, "Knowledge Based System for the Diagnosis of Dengue Disease," Int. J. Acad. Heal. Med. Res., vol. 3, no. 4, pp. 12-19, 2019.

[40] E. K. Lee, F. H. Pietz, C. H. Chen, and Y. Liu, "An interactive web-based decision support system for mass dispensing, emergency preparedness, and biosurveillance," in ACM International Conference Proceeding Series, 2017, vol. Part F1286, pp. 137-146, doi: 10.1145/3079452.3079473.

[41] A. E. Lammers, C. Apitz, P. Zartner, A. Hager, K. O. Dubowy, and G. Hansmann, "Diagnostics, monitoring and outpatient care in children with suspected pulmonary hypertension/paediatric pulmonary hypertensive vascular disease. Expert consensus statement on the diagnosis and treatment of paediatric pulmonary hypertension. The European ," Heart, vol. 102, pp. ii1-ii13, 2016, doi: 10.1136/heartjnl-2015-307792.

[42] M. Karami and N. Hafizi, "E-game in Healthcare: As an E-intervention to Promote Public Health," Iran J Public Heal., vol. 45, no. 12, pp. 1662-1664, 2016, [Online]. Available: http://ijph.tums.ac.ir.

[43] C. Jin, W. Chen, Y. Cao, and Z. Xu, "Development and Evaluation of an AI System for COVID-19 Diagnosis," medRxiv, pp. 1-23, 2020.

[44] A. Maseleno and M. M. Hasan, "Avian influenza (H5N1) expert system using Dempster-Shafer theory," Int. J. Inf. Commun. Technol., vol. 4, no. 2-4, pp. 227-241, 2012, doi: 10.1504/IJICT.2012.048766.

[45] M. H. Daud et al., "The EMPOWER-SUSTAIN e-Health Intervention to improve patient activation and self-management behaviours among individuals with Metabolic Syndrome in primary care : study protocol for a pilot randomised controlled trial," pp. 1-16, 2020.

[46] L. Willem, T. V. Hoang, S. Funk, P. Coletti, P. Beutels, and N. Hens, "SOCRATES: An online tool leveraging a social contact data sharing initiative to assess mitigation strategies for COVID-19," medRxiv, p. 2020.03.03.20030627, 2020, doi: 10.1101/2020.03.03.20030627.

[47] D. Wilcke, S. Zacharias, Z. Jin, and F. Sieker, "GIS-based expert systems for Land Use Planning as a Contribution to Flood Mitigation," Eur. J. Nucl. Med. Mol. Imaging, vol. 35, no. 7, pp. 1350-6, 2008, doi: 10.1007/s00259-008-0739-8.

[48] Z. Neufeld, H. Khataee, and A. Czirok, "Targeted adaptive isolation strategy for Covid-19 pandemic," medRxiv, vol. 1, p. 2020.03.23.20041897, 2020, doi: 10.1101/2020.03.23.20041897.

[49] S. S. Abu Naser and M. M. Al-Hanjori, "An expert system for men genital problems diagnosis and treatment," Int. J. Med. Res., vol. 1, no. 2, pp. 83-86, 2016.

[50] C. V. Cannistraci, "Age Adaptive Social Distancing: a nonlinear engineering strategy to contrast COVID-19 via precision and personalized mitigation," no. April, 2020, doi: 10.20944/preprints202004.0066.v1.

[51] M. Magdon-Ismail, "Machine Learning the Phenomenology of COVID-19 From Early Infection Dynamics," pp. 1-16, 2020, [Online]. Available: http://arxiv.org/abs/2003.07602.

[52] C. A. Hogan, M. K. Sahoo, and B. A. Pinsky, "Sample Pooling as a Strategy to Detect Community Transmission of SARS-CoV-2," JAMA Network: American Medical Association. American Medical Association, pp. 1-2, 2020, doi: 10.1056/NEJMp2002125.

[53] L. L. Dubenske, D. H. Gustafson, B. R. Shaw, and J. F. Cleary, "Web-Based cancer communication and decision making systems: Connecting patients, caregivers, and clinicians for improved health 
outcomes," Med. Decis. Mak., vol. 30, no. 6, pp. 732-744, 2010, doi: 10.1177/0272989X10386382.

[54] A. Fan, D. Lin, and Y. Tang, "Clinical Decision Support Systems for Comorbidity: Architecture, Algorithms, and Applications," Int. J. Telemed. Appl., vol. 2017, 2017, doi: 10.1155/2017/1562919.

[55] D. Meidan, R. Cohen, S. Haber, and B. Barzel, "An alternating lock-down strategy for sustainable mitigation of COVID-19," pp. 1-14, 2020, [Online]. Available: http://arxiv.org/abs/2004.01453.

[56] K. R. R. Gandhi, K. V. R. Murthy, S. S. P. Rao, and F. Casella, "Non-Pharmaceutical Interventions ( NPIs ) to reduce COVID-19 mortality," GITAM Institute of Medical Sciences and Research (GIMSR), 2020. [Online]. Available: https://ssrn.com/abstract=3560688.

[57] Yusa. Muhammad, Erlansari. A, Haryani L, Ernawati, Liya Agustin Umar "Sistem Pakar: Implementasi Metode Bayes Probabilties untuk Penentuan Kriteria Pasien COVID 19 Berdasarkan Fitur Gejala" Jurnal teknologi informasi dan terapan (J-TIT), vol 8, No. 1, Juni 2021, https://doi.org/10.25047/jtit.v8i1.222 